\title{
Ny kold krig - Marie Krarup taler med 17 eksperter fra øst og vest
}

\author{
Marie Krarup \& Matthew Dal Santo (red.) \\ Gjern: Forlaget Hovedland 2018 \\ 367 sider. ISBN 9788770706100
}

Omtalt av Tormod Heier [oberstløytnant og forsker ved Forsvarets høgskole, theier@fhs.mil.no]

Den danske politikeren Marie Krarup fra Dansk Folkeparti har sammen med bokens redaktør, Matthew Dal Santo, laget en debattbok det er verdt å lese. Nå skal man alltid være forsiktig med å lese bøker skrevet av politikere. For mellom linjene til forfattere med politiske ambisjoner følger også underliggende motiver, altså ønsker om å påvirke andre i én bestemt retning. Dette er oftest underkommuniserte intensjoner. Med de strekker seg alltid lenger enn den altruistiske vitenskapens fromme ønske om å fremskaffe uhildet kunnskap.

Likevel er det noe ærlig og inderlig over Krarups ønske med boken. For selv har hun fått føle på kroppen hvordan det er å bli stigmatisert, latterliggjort og karikert. Ikke minst fordi hun på uredd vis har utfordret det politisk korrekte: det liberale og inkluderende danske fellesskapet. For ifølge Krarup er det ikke Russland som er vår tids fiende, noe den danske regjering hardnakket påstår. Snarere er det «ukontrollert innvandring og islamisering» (s. 7). Dermed blir EU en større trussel, mot så vel dansk frihet som vestlige verdier. Dette er rett og slett fordi EU overtar nasjonalstatlige kontrollmekanismer der folket selv «(...) kan træffe beslutninger og gjennemføre praktiske foranstaltninger til at begrænse indvandringen og dermed islamiseringen» (ibid).

Krarups poeng er derfor å bidra til et mer nyansert debattklima som altfor ofte preges av russofobiske holdninger. For det er bare gjennom mer kunnskap at øst og vest kan forstå hverandre, kvitte seg med fordommer og gjøre Europa klar til å møte de største truslene: EU og innvandring. Derfor har hun oppsøkt forskere, kommentatorer og politikere i Russland, Latvia, Ukraina, Storbritannia, Danmark, USA og Canada. Flere av dem er hun sterkt uenig med, særlig de som mener at Russland er opportunistisk, ekspansjonistisk, revansjistisk, uforutsigbar og farlig. Og akkurat det er prisverdig. Balansen mellom ulike syn kommer bedre frem, kontraster og motsetninger likeså. Politikeren fra Dansk Folkeparti vil ikke bare fremme egne standpunkter. Også skeptikere mot en «mykere» eller mer «ettergivende» Russland-politikk gis 
plass for å vise at det er «(...) mange forskellige måder at forholde seg til situasjonen på» (s. 359).

Men tross gode intensjoner fra en engasjert Folketingsrepresentant på dansk høyreside: Boken må, som alle andre kilder, forstås i lys av sin samtid. Bokens kontekstuelle bakteppe er, slik jeg tolker det, et Europa som knaker i sammenføyningene. Et Europa der høyrepopulismen er på fremmarsj og hvor millioner av velgere samles rundt noen felles prosjekter: mot islams innflytelse i Europa, mot EU, mot en politisk og økonomisk elite som har glemt de svakeste i samfunnet. Dette er borgere som føler seg fremmedgjort i egne land, og som hadde stor forstålse for de over 17 millioner britene som stemte for Brexit i juni 2016. De nærmere 63 millioner velgerne som brakte Donald Trump til makten noen måneder senere kan ses som et amerikansk uttrykk for den samme bevegelsen. Boken synliggiør en høyrepopulistisk tidsånd preget av spektakulære terroranslag mot Europa. Men også innvandring og økonomiske problemer grunnet avindustrialisering og global konkurranseutsetting av sårt tiltrengte arbeidsplasser. Hverken forskere, «mainstream»-medier eller etablerte politiske partier har vist særlig interesse for hvordan «mannen i gata» opplever disse problemene på kroppen. Slik sett kan boken leses som et ønske om å få Europa tilbake til sine verdikonservative røtter.

Krarups ønske om å nyansere Russland-debatten synliggjør dermed et større fenomen, nemlig fremveksten av et paneuropeisk konservativt prosjekt. Vi snakker om høyrepopulistiske partier og grasrotbevegelser som ønsker å ta et oppgiør med de liberale «-ismene»: verdier som vant frem da den kalde krigen ble vunnet. Og som EU og NATO bruker for å få Russland til å bli som oss: et liberalt demokrati, med en rettsstat som fremmer det subjektive, det individuelle, det materialistiske og det hedonistiske. Dette er også en av hovedkonklusjonene etter 17 ekspertsamtaler. For først siteres bokens mest interessante, lærerike og tankevekkende ekspert, Aleksandr Sjtjipkov:

[Uenigheten mellom Russland og Vesten] dreier seg om Europas og Ruslands åndelige genfødsel. Vi har taget initiativet, når det drejer seg om genkristning. Men vi håper, at Vesten meget hurtigt indhenter oss. Vi kunne godt tænke os at vise, at trofasthed over for traditionen samt demokrati i et samfund kan gå hånd i hånd. Russland og Europa har brug for hinanden. Det er en viktig forutsætning for gensidig overlevelse (s. 366).

Deretter følger hun selv opp med det som på mange måter har gått som en rød tråd gjennom samtalene, især med de østlige ekspertene:

Der er ikke Russland, der truer os (...) men det er først og fremst vores egen manglende vilje til at erkende, hvad vi kommer af, hvilke verdier vi står på, og hvilke verdier vi derfor skal forsvare i fremtiden, der truer os. Som det er nu, er vi i Vesten forblændet af troen på menneskerettighedernes og det vestlige demokratis saliggiørende virkninger. Denne erstatningsreligion gør Russland til vores fjende og forhindrer os $i$ at erkende vores kulturs sande rødder, som blandt andet er kristendommen (ibid).

Derfor mener jeg denne boken er viktig. Ikke fordi jeg deler Krarups syn, men fordi hun gjør opprør mot den politiske korrektheten som preger danske, svenske, finske 
og norske myndigheter. Spørsmålene hun stiller, er stort sett balanserte og åpne. Ekspertene får dessuten snakke fritt, "rett fra levra». Det giør inntrykk når lojale embedsmenn, som generalmajor Karsten Møller, tar «bladet fra munnen» og kommer med synspunkter som går på tvers av offisiell politikk. Derfor er det noe ærlig og befriende over boken. Det er rett og slett fordi Krarup og Dal Santo tar et oppgjør med politikere, journalister og akademikere som straffer annerledestenkende, som stigmatiserer, latterliggjør og beskylder meningsmotstandere for å fremme russisk propaganda. Løsrevet fra selvsensur, gruppetenkning og et meningstyranni som sementerer fordommer og uvitenhet, er boken vel verdt å lese. Om du er forsker, student, politiker, ansatt i embetsverket, eller bare samfunnsengasjert borger: Løp og kjøp! 